\title{
STRATEGY, CORPORATE CULTURE, STRUCTURE AND OPERATIONAL PROCESSES AS THE CONTEXT FOR THE INNOVATIVENESS OF AN ORGANIZATION
}

\author{
Katarzyna SZCZEPAŃSKA-WOSZCZYNA \\ The University of Dąbrowa Górnicza, Faculty of Applied Sciences \\ Department of Management, Dąbrowa Górnicza, POLAND \\ e-mail: kszczepanska@wsb.edu.pl
}

\begin{abstract}
The paper refers to relationships between the innovativeness of an organization and its selected determinants such as strategy, corporate culture, structure and operational processes. Research was conducted among 200 managers at the top, middle and operational levels of management (200 companies operating in Poland implementing innovations - innovative companies). Conditions leading to innovations are described as the combination of processes, which result from the internal and external dynamics of a given entity. The analysis assumed that the assessment of company innovativeness would be based on an assessment of whether the company is a leader in the industry in terms of new products (the higher the rating, the more innovative the company is considered to be). The relationship between the dimensions of the company's functioning and the degree of its innovativeness was rated on the basis of two measures: the Spearman's rank correlation coefficient and the chi-square coefficient. It was assumed that the most innovative companies have structures similar to organic ones, with a weak influence of the elements of mechanistic structures. This assumption was proven in relation to features of organizations considered important for innovativeness.
\end{abstract}

Keywords: innovation, innovativeness, strategy, structure, corporate culture, operational processes, innovation determinants.

JEL: L21, M14, O31.

\section{Introduction}

Innovations arise in conditions that are a combination of processes resulting from the internal and external dynamics of an organization. The numerous, different and complex conditions of organization innovativeness include external factors, for example, market competition conditions, technologies, government activities, a stage in the industry/sector life cycle stage, environment dynamics and degree of uncertainty (De Tienne \& Mallette, 2012, p.1) or general characteristics of environment, such as changeability (dynamism), complexity and hostility (Miller \& Friesen, 1983).

Internal factors include the broadly defined qualities of managers (Vaccaro, et al., 2012; SzczepańskaWoszczyna \& Dacko-Pikiewicz, 2014), their management style, organizational culture (SzczepańskaWoszczyna, 2014), company profile (Arad, et al., 1997; Crossan, Apaydin, 2010), strategy (ForemanPeck, et al., 2006; Hurley \& Hult, 1998; Zdunczyk \& Blenkinsopp, 2007), organizational structure (Aiken \& Hage, 1971; Francik, 2003; Kimberly \& Evanisko,
1981; Zakrzewska-Bielawska, 2011), human resources (HR) (Koval'ová, 2016) and others.

On the other hand, as a result of a badly constructed system of company organization, innovative processes are inherently inhibited. Each innovative action is essentially subjective, however a certain range of general and specific conditions that can trigger innovation or foster the innovation implemented can be determined. Based on literature research, it is assumed in the paper that special attention should be paid to the role that the organizational structure, organizational culture, strategy, procedures and operational processes play in the development of company innovativeness (Szczepańska-Woszczyna, 2016).

\section{Elements forming the organizational context as the determinant of company innovativeness}

The choice of strategy, structure, organizational culture, and operational processes as an area of analysis 
allows for focusing on such elements that are controlled by the organization, leaving others that are outside. They underlie structures and systems that condition and support innovation in an organization.

- An organizational structure

An organizational structure is defined as the arrangement of the organization's components and specific relationships between them that are specific to the given system. It is a relatively stable division of tasks, power and information, defining the distribution of control and responsibility in the organization, conditioning the formation of teams, and the coordination and division of tasks between organizational units and employees (Daft, 1978).

The organizational structure is an important factor both supporting and limiting innovativeness (Aiken \& Hage, 1971, Damanpour, 1991; Pichlak, 2012, Subramanian \& Nilakanta, 1996).

The creation of organizational structures that make inter-organizational sharing of knowledge and resources possible, allows for making strategic decisions, reconciling contradictions, and actively and effectively coordinating the innovation process (Olson \& Walker Jr, 1995).

Direct control of the organizational structure gives the opportunity to influence the organization innovativeness (also through its sub-dimensions, i.e., formalization, centralization, specialization, functional differentiation, and hierarchical (vertical) differentiation (Damanpour, 1991), as well as variables related to resources, processes and culture).

Standardization and specialization appearing along with an increased size of the organization lead to greater effectiveness, but in exchange for inflexibility and bureaucratization.

The centralization of a decision-making process is a method for regulating and controlling the behavior of employees, it also determines the degree of freedom for employees in making decisions. Research conducted by Severo, et al. (2015) indicated that innovations are significantly supported more by the horizontal than the vertical organizational structure.

Mechanistic organizations operating on principles similar to machines are not conducive to innovation; they are not susceptible to changes, are based on the specialization of activities, they operate under rigid rules based on formal relationships between employees, and the centralization of power in the hands of several top managers. The organic and adaptive structures assume freedom and the use of one's own mind, and the development of creativity and imagination. Imagination is more important in them than formal qualifications (Francik, 2003).

Organic organizational structures are considered more effective in terms of innovativeness. Innovativeness is fostered by the low degree of formalization and centralization, low management spread, fluid scope of duties and emphasis on horizontal communication (Pichlak, 2012).

\section{- Strategy}

Strategy is a concept of systemic operation based on a defined set of long-term goals, specific resources and means to achieve these goals, and procedures that ensure their optimal arrangement and use (Penc, 1994, p.180).

The condition of the effective and rational introduction and commercialization of innovations in the domestic and foreign market is the necessity (need) for innovative management and the formulation of innovation strategies (Janasz, 2011, p.47).

Due to the dynamics, complexity and unpredictable changeability of the environment, the implementation of the strategy involves not only the implementation of the scenario developed, but also strategic, creative flexibility is necessary. Innovations are often the reaction of companies to changes in the environment; therefore, they should be examined from various strategic perspectives.

Innovative processes in companies require solving problems, to which model strategic solutions can be applied. These include the sources of innovative ideas, methods for implementing these processes, the protection of innovative solutions, the pace of innovation and the degree of commitment in innovative activities.

The nature of the rapidly changing environment that favors innovation forces dynamic and innovative strategy. The strategy must precede trends and phenomena appearing in the market, which are usually the result of innovative activities of other companies (Mirski, 2014). The basic element of introducing 
change is changing corporate strategy. This also entails changes in the structure, the team of employees, culture and processes taking place in the organization (Grudzewski \& Hejduk, 2000).

Strategic decisions on business expansion, innovation and personnel strategies shape attitudes and, as a consequence, values and norms change. At the same time, a company with an open, entrepreneurial and flexible structure will be more open and flexible in developing the assumptions of its strategy.

\section{- An organizational culture}

An important factor, which is considered by many authors as crucial, is organizational culture (Jassowalla \& Soshittal, 2002; Loewe \& Dominiquini, 2006; Lyons, et al., 2007; Tellis, et al., 2009). Researchers agree on its positive importance for innovation (Chang \& Lee, 2007; Higgins \& McAllaster, 2002; Lau \& Ngo, 2004; Martins \& Terblanche, 2003).

To successfully implement innovation or adopt technological solutions, companies must meet certain conditions in terms of their internal behaviors and external relationships (Tylecote, 1996).

The elements of culture have a twofold impact on innovation - through socialization and coordination (Tesluk, et al., 1997). Through socialization, each member of the organization can ensure whether creative and innovative behavior is part of its business model. At the same time, an organization can, through actions, policies and procedures, generate values that support creativity and innovation, so that its innovative capabilities will consistently improve.

Organizational culture understood in this way is identified with a culture of innovation. Organizational culture can stimulate the innovative behavior of organization members, lead to their adoption of innovation as the fundamental value in the organization (Hartmann, 2006). Organizational culture focused on promoting behaviors supporting organization innovativeness is a source of norms, values, ways of acting and thinking that will support the process of creating innovation.

Maintaining the global balance depends on the mutual adjustment of participants to specific situations. A.K. Koźmiński believes that managers must change organizational cultures to implement proper new strategies that ensure survival in a changing market environment. It is the change in organizational cultures that determines such adjustments (Koźmiński, 1998). The change in the organization must be followed by a change in the organizational culture.

By differentiating organizational culture by results achieved by the organization, the following can be identified:

1) positive (constructive) culture, which is characterized by susceptibility to changes and acceptance of changes. It contributes to using the creative potential to a large extent, thus increasing the ability to achieve the goals set, reward employees who solve the emerging problems by themselves, motivating them to work efficiently;

2) negative culture (biuropathology), which limits creativity, creates conservatism, lack of flexibility, leads to a situation of antipathy, in which members of the organization become opponents rather than supporters.

In past-oriented organizations, the conservative culture prevails, while in future-oriented organizations, a culture of innovation dominates.

In the conservative culture, importance is attached to values, norms and symbols; traditions, rules and regulations are valued, because they give a sense of safety and certainty. Employees value stabilization rather than change, they have no development ambitions or motivation for achievement. Changes face strong resistance.

In a culture of innovation, values are respected, but they are treated instrumentally; when they cease to be useful, they are replaced with new ones. Risk is willingly taken; creativity, dynamism and a high sense of responsibility are valued; changes are made and the focus is on development, which allows an organization to function effectively in the changing and stormy environment. This type of culture promotes dynamism and change, and employees take up challenges willingly (Zbiegień-Maciąg, 1999).

In the typology developed by Goffee and Jones (2001), organizational culture is differentiated by two criteria: sociability and solidarity. Sociability can be defined as kindness in the relationships between people in the organization. Through acquaintances and friendships, ideas, attitudes, interests and 
values become common for the members of the organization. Solidarity, on the other hand, is the ability of people to efficiently and effectively achieve common goals.

Thus, the culture of community, the culture of mercenary, a network culture and a fragmentary culture can be distinguished. The mercenary culture is a good basis for introducing change - this type of culture puts emphasis on strategy and winning in the market. Organization members have clear priorities and act quickly in response to changes in the environment. The culture of mercenary will be able to achieve greater efficiency and effectiveness in the organization. A positive attitude to change is also a feature of the network culture (SzczepańskaWoszczyna \& Dacko-Pikiewicz, 2015).

Organizational culture is inseparable from strategy. The organizational culture should be shaped in such a way as to support the strategy, while the strategy itself also determines the organizational culture. The strategy determines the trend in the development of organizational culture (a strategically oriented culture), while culture sets a framework that constitutes strong limitations in the process of corporate strategy implementation (Krupski \& Stańczyk, 2009, p.8).

Culture follows strategy, strategic decisions on business expansion, innovation and personnel strategies shape attitudes, and thus change values and norms.

Organizational culture also has a significant impact on the functioning of the company's operational systems and the organization of its structures, including the degree of flexibility within structures, the flexibility of communication channels, the scope of power decentralization, a number of levels in the organization hierarchy, the scope of managerial control, and individual/group decision making.

- Procedures and operational processes

Procedures and operational processes are relatively stable action programs within the organization. These programs may concern both the operation of the core business (e.g., maintenance, scientific and technical information service), regulate this activity (e.g., the procedure of the technical preparation of production), or support the activity of the organi- zation as a whole (e.g., personnel management, legal services).

They refer to such aspects of the company's activity as leadership, motivating, getting others involved, making changes, working in teams, planning and corrective actions. Their course depends on the policies, regulations, systems and structures of the company. They can cover the entire organization, or its separate part.

Procedures and operational processes are of particular importance in the process of eliminating the standard, predictable, routine, and repeatable imbalance. A relationship between the development of the organization and the evolution of procedures and operational processes is observed (Karpacz, 2013). They are a fairly constant and unchanging elements, characteristic of the entire organization. They make it possible to adapt the rules of operation to specific situations, thus restoring the balance, because the repeatable occurrence of certain situations leads to the standardization of rules of conduct (Koźmiński \& Obłój, 1989).

In the process of adapting to changes resulting from changes in the environment, the mismatch of procedures and operational processes for the efficient performance of tasks may result in the organization ceasing to exist in some cases. Thus, although the procedures are a manifestation of the organization's striving for stability, it does not mean that it is necessary to look for new patterns of behavior.

The increased dynamics of the environment pushes the company to change the behavior, and thus, change operational procedures adequately to changes in the organization's environment. At the same time, managers should initiate changes because in stable conditions, employees do not think about what they do routinely, unreflectively but according to procedures, while during changes, they feel the need to identify what was before, compared to the new routine patterns of behavior (Karpacz, 2013).

Research results indicate that even the not very dynamic companies are able to strengthen their position in the market through innovation, if entrepreneurs and managers are willing to take risks and be more active than competitors. Much also depends on their management style and the atmosphere created within 
the company. Thanks to these companies, the process of creating innovation, considered as a social process, becomes more effective.

Communication (the exchange of information and ideas), which is made easier in such conditions, becomes a particularly stimulating factor.

The degree of company innovativeness can also be strengthened by consistent implementation and adherence to the principles of creativity: extensive learning processes, conducting research generating new knowledge, communicating (interaction) with people with knowledge, using traditional and unconventional thinking processes, using a holistic approach to problem solving, encouragement and support for passion and creating the environment that is conducive to creativity.

\section{Methodology}

The purpose of research was to determine whether there is a relationship between the dimensions of the company such as the structure, strategy, organizational culture, operational processes and the degree of its innovativeness.

The analysis assumed that the assessment of company innovativeness would be based on an assessment of whether the company is a leader in the industry in terms of new products (the higher the rating, the more innovative the company is considered to be).

In quantitative research, a standardized interview questionnaire was used, consisting of three parts (15 questions in total) and respondent's particulars.

A five-point measuring scale was used, in which:

$$
\begin{aligned}
& 1 \text { - meant insignificant, } \\
& 2 \text { - small importance, } \\
& 3 \text { - medium importance, } \\
& 4 \text { - big importance, } \\
& 5 \text { - very important. }
\end{aligned}
$$

The relationship between the dimensions of the company's functioning and the degree of its innovativeness was rated on the basis of two measures: the Spearman's rank correlation coefficient and the chi-square coefficient. The choice of measures was determined by the level of the measurement of variables.

The size of the research sample was 200 managers / 200 enterprises implementing innovation (innovative companies) from sectors characterized by a high degree of innovativeness such as telecommunications, IT, pharmaceutical, energy and finance and science sectors and industry.

The sample was diversified by the size of the company (i.e., the number of employees):

$1 / 3=$ companies with up to 50 employees,

$1 / 3=$ companies with 51 to 250 employees,

$1 / 3=$ companies with 251 employees and more.

Respondents were managers from:

- senior ( $43 \%$ of respondents),

- middle (47\%), and

- operational levels of management (10\%),

involved in the implementation of innovations in companies, people who have knowledge, decide or decide jointly on the company's policy in the field of innovation (depending on the company, these were, for example, people involved in research and development, production, and technology).

Research was conducted in April-May 2016 by means of the interview method, using computeraided telephone interviews (CATI). Calculations were performed using IBM SPSS Statistics 24.

\section{The organizational context of innovative- ness in light of research findings}

- Strategy and the degree of innovativeness

Table 1 presents the rating of the relationship between the individual elements of corporate strategy and the degree of company innovativeness.

The results indicate that there is a positive relationship between the elements of corporate strategy and the degree of company innovativeness. The relationship is statistically significant for the vast majority of factors. The strongest impact on the degree of company innovativeness was observed for:

1) building the market leader position in the field of new products and technologies; 
2) emphasis on the innovative character of solutions, processes and products in all departments of the organization.
The higher these factors were rated by the respondents, the higher company innovativeness was rated.

Table 1. Strategy and innovativeness (Spearman's rank correlation coefficient)

(Source: Own study based on direct research)

\begin{tabular}{|l|c|}
\hline \multicolumn{1}{|c|}{ Characteristics of company's development strategy } & $\begin{array}{c}\text { Correlation } \\
\text { coefficient }\end{array}$ \\
\hline $\begin{array}{l}\text { The organization anticipates product and technological changes in the industry and is the first } \\
\text { to launch novelty products in the market }\end{array}$ & $0.425^{* *}$ \\
\hline $\begin{array}{l}\text { All departments of the organization emphasize the innovative character of their solutions, } \\
\text { processes and products }\end{array}$ & $0.424^{* *}$ \\
\hline The organization conducts research and development work on new technologies & $0.327^{* *}$ \\
\hline $\begin{array}{l}\text { Benchmarking is used to assess the degree of technological, product and quality development } \\
\text { in the industry }\end{array}$ & $0.294^{* *}$ \\
\hline The organization analyzes the development of technology in a given industry & $0.176^{*}$ \\
\hline $\begin{array}{l}\text { Building knowledge in the organization is of strategic importance to the management board } \\
\text { of the company in the process of gaining competitive advantage }\end{array}$ & $0.145^{*}$ \\
\hline $\begin{array}{l}\text { The organization has a described business strategy covering all business processes, } \\
\text { which is clearly communicated by the management board of the company }\end{array}$ & 0.110 \\
\hline $\begin{array}{l}\text { Innovative activities and thinking of managers and employees is "embedded" } \\
\text { in the organization's development strategy }\end{array}$ & 0.104 \\
\hline
\end{tabular}

* statistical significance at the level of 0.05

** statistical significance at the level of 0.01

- Structure and the degree of innovativeness

The results of analysis of the impact of determinants of the company's organizational structure on the degree of its innovativeness are presented in Table 2.

The negative but statistically insignificant relationship was observed for the impact of the formalization of instructions and procedures on the degree of innovativeness. However, the influence of other factors is statistically significant, such as:

1) engaging suppliers in the process of developing new products;

2) eliminating barriers to information flow between departments and individual employees;

3) constant development of communication channels and tools for acquiring and collecting knowledge.
The higher the respondent rates these factors, the more innovative the company is.

- Organizational culture and the degree of innovativeness

Table 3 presents the results of analysis of the relationship between the determinants of company's organizational culture and the degree of its innovativeness.

The positive relationship between the rating of individual elements of organizational culture and the degree of company innovativeness was observed.

It turned out to be statistically significant in the case of three factors, namely:

1) enabling employees to generate new ideas, changes, experiments, and new ideas aimed at innovation; 
Table 2. Structure and innovativeness (Spearman's rank correlation coefficient)

(Source: Own study based on direct research)

\begin{tabular}{|l|c|}
\hline \multicolumn{1}{|c|}{ Characteristics of the company structure } & $\begin{array}{c}\text { Correlation } \\
\text { coefficient }\end{array}$ \\
\hline Engaging suppliers in the process of developing new products & $0.236^{* *}$ \\
\hline $\begin{array}{l}\text { Elimination of barriers to information flow between departments and individual employees by } \\
\text { managers }\end{array}$ & $0.182^{*}$ \\
\hline $\begin{array}{l}\text { Constant development of communication channels and tools for acquiring and gathering } \\
\text { knowledge in the organization }\end{array}$ & $0.145^{*}$ \\
\hline $\begin{array}{l}\text { The goals and plans of action in the organization take into account the requirements of custom- } \\
\text { ers, the needs of internal and external stakeholders, also of the public }\end{array}$ & 0.118 \\
\hline $\begin{array}{l}\text { The organization has clear instructions, templates of documents and procedures that are under- } \\
\text { standable and available to employees }\end{array}$ & -0.035 \\
\hline
\end{tabular}

* statistical significance at the level of 0.05

** statistical significance at the level of 0.01

Table 3. Organizational culture and innovativeness (Spearman's rank correlation coefficient) (Source: Own study based on direct research)

\begin{tabular}{|c|c|}
\hline Characteristics of organizational culture & $\begin{array}{l}\text { Correlation } \\
\text { coefficient }\end{array}$ \\
\hline $\begin{array}{l}\text { Employees have time and resources to generate new ideas, changes, experiments, } \\
\text { new ideas aimed at innovation }\end{array}$ & $0.218^{* *}$ \\
\hline $\begin{array}{l}\text { Employees are rewarded for innovative technological, product, organizational, } \\
\text { and marketing solutions }\end{array}$ & $0.180^{*}$ \\
\hline $\begin{array}{l}\text { The organization creates short-term and long-term action plans, which are regularly monitored } \\
\text { and verified }\end{array}$ & $0.154^{*}$ \\
\hline The organization has a defined mission that is communicated and known to all employees & 0.138 \\
\hline $\begin{array}{l}\text { Managers share knowledge of the future direction of the organization's development } \\
\text { with employees }\end{array}$ & 0.137 \\
\hline $\begin{array}{l}\text { Managers actively support change and implement a culture of improvement, learning } \\
\text { and innovation in the organization }\end{array}$ & 0.136 \\
\hline $\begin{array}{l}\text { Employees' creativity is supported by training, building project teams, meetings } \\
\text { and discussions between different task teams, and so on. }\end{array}$ & 0.136 \\
\hline Each employee can submit a new idea, improvement, or change & 0.105 \\
\hline The knowledge and skills of employees are systematically improved & 0.104 \\
\hline $\begin{array}{l}\text { Employees have a possibility of co-deciding on the scope of changes introduced } \\
\text { in the organization }\end{array}$ & 0.002 \\
\hline
\end{tabular}

* statistical significance at the level of 0.05

** statistical significance at the level of 0.01 
2) rewarding employees for innovative technological, product, organizational, and marketing solutions; 3) creating short and long-term action plans, which are regularly monitored and verified. The higher the respondents rated these factors, the higher the degree of company innovativeness was. The increased rating of individual factors is related to the increased degree of organization innovativeness.

- Procedures and operational processes and innovativeness

Table 4 presents the results of measuring the strength and direction of the relationship between the rating of factors determining operational processes in a company and the degree of its innovativeness.

The results of the correlation analysis show that the respondents' ratings of the factors determining procedures and operational processes in the company are related to the degree of company innovativeness.
The relationship is positive for almost all factors. An exception is an element related to the functioning of instructions, document templates and procedures understandable to employees in the organization. However, this relationship is very weak, negative, and statistically insignificant.

Taking into account other factors, a statistically significant relationship was demonstrated for many of them, and the strongest impact was observed for the following characteristics:

1) using benchmarking to assess the degree of technological, product and quality development in our industry;

2) the development and management of intellectual resources by filing and purchasing patents, licenses and copyright. It can be concluded that if the respondent rated these factors highly, the company was probably characterized by a higher degree of innovativeness.

Table 4. Procedures and operational processes and the degree of innovativeness

(Spearman's rank correlation coefficient)

(Source: Own study based on direct research)

\begin{tabular}{|c|c|}
\hline Characteristics of the company's operational processes & $\begin{array}{l}\text { Correlation } \\
\text { coefficient }\end{array}$ \\
\hline $\begin{array}{l}\text { Benchmarking is used to assess the degree of technological, product and quality development } \\
\text { in the industry }\end{array}$ & $0.294^{* *}$ \\
\hline $\begin{array}{l}\text { The company develops and manages intellectual resources by filing and purchasing patents, } \\
\text { licenses, and copyright }\end{array}$ & $0.255^{* *}$ \\
\hline Suppliers are involved in the process of developing new products & $0.236^{* *}$ \\
\hline $\begin{array}{l}\text { The statistical measures and techniques are used to improve processes and reduce deviations } \\
\text { from the achievement of results assumed }\end{array}$ & $0.233^{* *}$ \\
\hline $\begin{array}{l}\text { Customers' opinions on the products/services of the organization are collected, which are taken } \\
\text { into account in the process of developing products }\end{array}$ & $0.169^{*}$ \\
\hline Quality management standards are introduced into processes in the organization & $0.159^{*}$ \\
\hline $\begin{array}{l}\text { The organization constantly develops communication channels and tools of acquiring } \\
\text { and gathering knowledge }\end{array}$ & $0.145^{*}$ \\
\hline $\begin{array}{l}\text { The organization has clear instructions, templates of documents and procedures } \\
\text { that are understandable and available to employees }\end{array}$ & -0.035 \\
\hline
\end{tabular}

* statistical significance at the level of 0.05

** statistical significance at the level of 0.01 


\section{Conclusion}

The organizational determinants of company innovativeness indicate the need for a holistic view of the functioning of the organization.

In the conditions of developing an innovationoriented culture, flexible organizational structure, and innovative strategy, organizations are willing and able to implement innovations.

Expectations regarding the features of organizations important for innovation were confirmed to a large extent.

The impact of certain activities on the degree of innovativeness, which, when combined, determine a specific type of strategy, structure, culture, and processes, was found.

It was assumed that the most innovative companies have structures similar to the organic ones, with a weak influence of the elements of mechanistic structures.

There are good supervisor-subordinate relationships in them, a democratic management style, low formalization, little centralism, a strategy of continuous innovation and a culture of innovation. This assumption was proven in relation to features of organizations considered important for innovativeness.

Research showed that companies use various strategic planning instruments and have a defined mission or specific goals that are monitored and communicated to employees.

\section{References}

[1] Aiken, M., Hage, J., 1971. The Organic Organization and Innovation. Sociology, 5(1), pp.63-82.

[2] Arad, S., Hanson, M.A., Schneider, R.J., 1997. A Framework for the Study of Relationships Between Organizational Characteristics and Organizational Innovation. The Journal of Creative Behavior, 31(1), pp.42-58.

[3] Armstrong, M., 1992. Zarzqdzanie zasobami ludzkimi (Human Resources Management). Kraków: Wyd. Profesjonalnej Szkoły Biznesu.
[4] Borowiecki, R., Siuta-Tokarska, B., 2015. Konkurencyjność przedsiębiorstw i konkurencyjność gospodarki Polski - zarys problemu (Competitiveness of Companies and the Polish Economy - an Outline of the Issue). Nierówności Społeczne a Wrrost Gospodarczy, 41, pp.52-66.

[5] Chang, S.-C., Lee, M.-S., 2007. The Effects of Organizational Culture and Knowledge Management Mechanisms on Organizational Innovation: An Empirical Study in Taiwan, The Business Review, 7(1), pp.295-301.

[6] Crossan, M. M., Apaydin, M., 2010. A Multidimensional Framework of Organizational Innovation: A Systematic Review of the Literature, Journal of Management Studies, 47(6), pp. 1154-1191, cited after: T. Kraśnicka, W. Głód, 2015. Poziom innowacyjności kadry kierowniczej najwyższego szczebla w polskich przedsiębiorstwach (The Degree of Innovativeness of Top Managers in Polish Companies), Studia Ekonomiczne, 212, pp.70-90.

[7] Daft, R.L., 1978. A Dual-Core Model of Organizational Innovation. Academy of Management Journal, 21(2), pp.193-210.

[8] Damanpour, F., 1991. Organizational Innovation: A Meta-Analysis of Effects of Determinants and Moderators. Academy of Management Journal, 34(3), pp.555-590.

[9] De Tienne, D., Mallette, P., 2012. Antecedents and Outcomes of Innovation-Oriented Cultures. International Journal of Business and Management, 7(18).

[10] Firlej, K., Żmija, D., 2014. Transfer wiedzy $i$ dyfuzja innowacji jako źródło konkurencyjności przedsiębiorstw przemystu spożywczego w Polsce (The Transfer of Knowledge and the Diffusion of Innovation as a Source of the Competitiveness of the Polish Food Industry). Kraków: Fundacja Uniwersytetu Ekonomicznego w Krakowie.

[11] Foreman-Peck, J., Makepeace, G., Morgan, B., 2006. Growth and Profitability of Small and Medium-sized Enterprises: Some Welsh Evidence. Regional Studies, 40(4), pp.307-319.

[12] Francik, A., 2003. Sterowanie procesami innowacyjnymi $w$ organizacji (Controlling In- 
novative Processes in the Organization). Kraków: Wydawnictwo Akademii Ekonomicznej w Krakowie.

[13] Goffee, R., Jones, G., 2001. Why Should Anyone Be Led by You? In: D. Goleman, T.H. Davenport, J.C. Beck (eds.). On What Makes a Leader. Harvard Business Review, Boston.

[14] Grudzewski, W.M., Hejduk, I.K., 2000. Restrukturyzacja firmy jako kierunek wzrostu jej wartości (Company Restructuring as a Trend in Increasing its Value). Annales Universitatis Mariae Curie-Skłodowska. Sectio H. Oeconomia, 34, pp.25-57.

[15] Hartmann, A., 2006. The Role of Organizational Culture in Motivating Innovative Behaviour in Construction Firms. Construction Innovation, 6(3), pp.159-172.

[16] Higgins, J.M., McAllaster, C., 2002. Want Innovation? Then Use Cultural Artifacts that Support it. Organizational Dynamics, 31(1), pp.74-84.

[17] Hurley, R.F., Hult, G.T.M., 1998. Innovation, Market Orientation, and Organizational Learning: an Integration and Empirical Examination. The Journal of Marketing, 62(3), pp.42-54.

[18] Janasz, W., 2002. Innowacje $w$ modelach przedsiębiorstw (Innovation in the Models of Companies). Szczecin: Wydawnictwo Naukowe Uniwersytetu Szczecińskiego.

[19] Janasz, W., 2011. Strategie organizacji innowacyjnych (Strategies of Innovative Companies). Studia i Prace Wydziatu Nauk Ekonomicznych i Zarzadzania, 21.

[20] Jassowalla, A.R., Soshittal, H.C., 2002. Cultures That Support Product Innovation Processes. Academy of Management Executive, 16(3), pp.42-54.

[21] Karpacz, J., 2013. Procedury jako narzędzie utrwalania rekurencyjnych wzorów zachowań pracowników (Procedures as a Tool of Strengthening the Recursive Patterns of Employees' Behavior). Zarzadzanie $i$ Finanse, 4(2), pp.171180.

[22] Kimberly, J.R., Evanisko, M.J., 1981. Organizational Innovation: The Influence of Individual, Organizational, and Contextual Factors on Hos- pital Adoption of Technological and Administrative Innovations. Academy of Management Journal, 24(4), pp.689-713.

[23] Korpysa, J., 2014. Kultura innowacyjności mikroprzedsiębiorstw Spin Off (Innovation Culture of Spin-Off Companies). Studia Ekonomiczne, Zeszyty Naukowe Wydziałowe Uniwersytetu Ekonomicznego w Katowicach.

[24] Koval'ová, M., 2016. People in the Process of Innovation and as the Factor Increasing Business Performance. Forum Scientiae Oeconomia, 4(3), pp.15-26.

[25] Koźmiński, A.K., 1998. Odrabianie zaległości (Catching Up). Warszawa: Wyd. Naukowe PWN.

[26] Koźmiński, A.K., Obłój, K., 1989. Zarys teorii równowagi organizacyjnej (Outline of the Theory of Organizational Balance). Warszawa: Wyd. PWE.

[27] Krupski, R., Stańczyk, S., 2009. Wielopoziomowość relacji: strategia - kultura organizacji (Multidimensional Character of the StrategyOrganizational Culture Relationship). Przeglad Organizacji, 12.

[28] Lau, C.M., Ngo, H.Y., 2004. The HR system, Organizational Culture, and Product Innovation. International Business Review, 13(6), pp.685703.

[29] Loewe P., Dominiquini J., 2006. Overcoming the barriers to effective innovation. Strategy \& Leadership, No. 34(1), pp.24-31.

[30] Lyons, R.K., Chatman, J.A., Joyce, C. K., 2007. Innovation in Services: Corporate Culture and Investment Banking. California Management Review, 50(1), pp.174-191.

[31] Martins, E., Terblanche, F., 2003. Building Organisational Culture that Stimulates Creativity and Innovation. European Journal of Innovation Management, 6(1), pp.64-74.

[32] Miller, D., Friesen, P.H., 1983. Strategy-making and Environment: The Third Link. Strategic Management Journal, 4(3), pp.221-235.

[33] Mirski, A., 2014. Strategie innowacji w zarządzaniu przedsiębiorstwem (Innovation Strategies in Company Management). Zeszyty Naukowe. 
Organizacja i Zarzqdzanie, Politechnika Śląska, 74, pp.559-563.

[34] Olson, E.M., Walker Jr, O.C., Ruekert, R.W., 1995. Organizing for Effective new Product Development: The Moderating Role of Product Innovativeness, The Journal of Marketing, 59(1), pp.48-62.

[35] Penc, J., 1994. Strategie zarzqdzania (Management Strategies). Warszawa: Wyd. Placet.

[36] Pichlak, M., 2012. Uwarunkowani innowacyjności organizacji. Studium teoretyczne $i$ wyniki badań empirycznych (Determinants of Organization Innovativeness. A Theoretical Study and Empirical Research Findings). Warszawa: Difin.

[37] Poznańska, K., 2006. Czynniki sukcesu małych przedsiębiorstw w Polsce (Factors of Success of Small Companies in Poland). Ekonomika I Organizacja Przedsiębiorstwa (special issue), pp.90-94.

[38] Rogoda, B., 2005. Przedsiębiorczość i innowacje (Entrepreneurship and Innovation). Kraków: Wydawnictwo Akademii Ekonomicznej w Krakowie.

[39] Severo, E.A., Cruz, M.R., Dorion, E., Guimarães, J.C.F., Pereira, A.A., 2015. Organizational Structure of Innovative Enterprises in Brazil. Espacios, 19.

[40] Stańda, A., 2000. Kultura organizacyjna i strategia przedsiębiorstwa. Zwiazki, dopasowania, zmiana. W: Instrumenty zarzqdzania we wspótczesnym przedsiębiorstwie (Organizational Culture and Corporate Strategy. Relationships, Matches and Change. In: Management tools in a modern company). Vol. II, Poznań: Wydawnictwo Akademii Ekonomicznej w Poznaniu.

[41] Subramanian, A., Nilakanta, S., 1996. Organizational Innovativeness: Exploring the Relationship between Organizational Determinants of Innovation, Types of Innovations, and Measures of Organizational Performance. Omega, 24(6), pp.631-647.

[42] Szczepańska-Woszczyna, K., 2014. The Importance of Organizational Culture for Innova- tion in the company. Forum Scientiae Oeconomia, 2(3), pp.27-39.

[43] Szczepańska-Woszczyna, K., 2016. Kompetencje menedżerskie $w$ kontekście innowacyjności przedsiębiorstwa (Managerial Competencies in the Context of Company Innovativeness). Warszawa: Wyd. Naukowe PWN.

[44] Szczepańska-Woszczyna, K., Dacko-Pikiewicz, Z., 2014. Managerial Competencies and Innovations in the Company - The Case of Enterprises in Poland. Business, Management and Education, 12 (2), pp.266-282.

[45] Szczepańska-Woszczyna, K., Dacko-Pikiewicz, Z., 2015. Kultura organizacyjna - punkt wyjścia innowacyjności organizacji. W: Teoria i prakty$k a$ zarządzania $w$ obliczu nowych wyzwań (Organizational Culture - A Starting Point for Organization Innovativeness. In: J. Kaczmarek, W. Szymla (eds.). The Theory and Practice of Management in the Face of New Challenges),. Kraków: Fundacja Uniwersytetu Ekonomicznego w Krakowie, pp.31-40.

[46] Tellis, G.J., Prabhu, J.C., Chandy, R.K., 2009. Radical Innovation Across Nations: The Preeminence of Corporate Culture. Journal of Marketing Education Review, 73, pp.3-23.

[47] Tesluk, P.E., Farr, J.L., Klein, S.R., 1997. Influences of Organizational Culture and Climate on Individual Creativity. The Journal of Creative Behavior, 31(1), pp.27-41.

[48] Tylecote, A., 1996. Cultural Differences Affecting Technological Innovation in Western Europe. European Journal of Work and Organizational Psychology, 5(1), pp.137-147.

[49] Vaccaro, I.G., Jansen, J.J., Van Den Bosch, F.A., Volberda, H.W., 2012. Management Innovation and Leadership: The Moderating Role of Organizational Size. Journal of Management Studies, 49(1), pp.28-51.

[50] Zakrzewska-Bielawska, A., 2011. Relacje między strategią a strukturą organizacyjną w przedsiębiorstwach sektora wysokich technologii (The Relationship Between Strategy and Organizational Structure in Companies from the High Technology Sector). Zeszyty Naukowe. Rozprawy Naukowe, Politechnika Lódzka, pp.3-394. 
[51] Zbiegień-Maciąg, L., 1999. Kultura w organizacji. Identyfikacja kultur znanych firm (Culture in the Organization. The Identification of the Cultures of Famous Companies). Warszawa: Wyd. Naukowe PWN.
[52] Zdunczyk, K., Blenkinsopp, J., 2007. Do Organisational Factors Support Creativity and Innovation in Polish Firms? European Journal of InnoInnovation Management, 10(1), pp.25-40. 